\title{
Schwartz Method For Children Formula
}

National Cancer Institute

\section{Source}

National Cancer Institute. Schwartz Method For Children Formula. NCI Thesaurus. Code C161348.

A formula to estimate glomerular filtration rate in children that takes into account age, height, and serum creatinine. eGFR $(\mathrm{mL} / \mathrm{min} / 1.73 \mathrm{~m} 2)=\mathrm{k} \times$ Height $(\mathrm{cm}) /$ Serum creatinine $(\mathrm{mg} / \mathrm{dL})$ where $\mathrm{k}=0.33$ for pre-term babies, 0.45 for full-term babies and 0.55 for girls ages 1-13 or 0.70 for boys ages 1-13. (Schwartz G), Gauthier B. A simple estimate of glomerular filtration rate in adolescent boys. J Pediatr. 1985 Mar;106(3):522-6.) 